\title{
Türkiye'deki Güzel Sanatlar Liselerinin müzik dersi öğretim programlarının öğrenci alan seçimi üzerindeki etkileri üzerine bir araștırma
}

\section{Aylin Șengün*}

*Sorumlu yazar: İstanbul Devlet Türk Müziği Topluluğu Ses Sanatçısı, Koșuyolu Mh. İsmail Pașa Sk. No.66 Kadıköy / isTANBUL, Türkiye. aylinsengun@gmail.com, https://orcid.org/0000-0002-3640-3560

\begin{abstract}
Özet
Tanzimat sonrası Osmanlı batılılașmasında göze çarpan en önemli yeniliklerden biri eğitim alanında yapılmıștır. Çağın gerektirdiği eğitim modellerinin uygulanması için modern okulların açılması on dokuzuncu asrın sonlarına doğru hız kazanmıștır. Bunlar arasında üniversite ve lise dengi birçok müzik okulu yer alıyor. Batı müziği ekseninde verilen eğitim programları günümüze kadar benzer program ve müfredat dahilinde ulașmıștır. Özellikle İstanbul ve Ankara merkezli müzik yüksek okullarının belirlemiș olduğu ders içerikleri müzik eğitiminde etkin rol oynamıștır. Bu durum ülkemizde yer alan güzel sanatlar liselerinde de benzerlik gösteriyor. Türkiye'deki güzel sanatlar liselerinin ilki 1989 yılında dönemin Milli Eğitim Bakanı Avni Akyol tarafından İstanbul'da kurulmuștur. Güzel Sanatlar Liseleri bugün orta öğretim düzeyindeki müzik eğitiminin öncü kurumlarıdır. Konservatuvar ve güzel sanatlar fakültelerinde geçmișten bu yana uygulanan Batı eksenli müzik eğitim modelleri bu liselerde de görülmektedir. Bu araștırmada, ülkemizdeki Güzel Sanatlar Liselerinin müzik öğretim programında yer alan Batı Müziği, Türk Müziği ve Halk Müziği türlerindeki ders sayısı planlamalarının, müzik bölümündeki öğrenci sayılarına yansımasının incelenmesi amaçlanmıștır. Buna yönelik olarak Millî Eğitim Bakanlığı Öğrenci İșleri Daire Bașkanlığından alınan Güzel Sanatlar Liseleri öğrenci verileri ve 19.02.2018 tarihinde Talim ve Terbiye Kurulu Bașkanlığı tarafından yayımlanan Güzel Sanatlar Liseleri müzik öğretim programı derslerine ait haftalık ders çizelgelerindeki ders dağılımları incelenmiştir.
\end{abstract}

\section{Anahtar kelimeler}

güzel sanatlar lisesi, müzik, türk müziği, batı müziği, öğrenci

Müzik, bir toplumun kültürel mirasının gelecek nesillere aktarımında çok önemli rol oynayan unsurlardan birisidir. Dünya üzerindeki birçok toplum geçmișten gelen tarihi birikimlerini ve yașadıkları coğrafyanın kültürel değerlerini yansıtan müziklere sahiptir. Eğitim, bu kültür mirasının gelecek kușaklara aktarımında önemli bir araçtır. Dolayısıyla müzik eğitimi, toplumlarda uzun yıllar içinde oluşan ve toplumsal yașamın ortak bir ürünü olan kültürel hafızayı tașımak ve aktarmak görevini üstlenmiștir.

Türk toplumunun, kökleri bin yıldan daha önceye giden ve tarih yolculuğunda Abdülkadir Meragî, Safiyüddin Urmevî, Mevlana Celaleddin-i Rumî, Sultan II. Murad, Itrî, Dede Efendi, Dilhayat Kalfa, Sultan III. Selim, Zekai Dede, Sadettin Kaynak, Münir Nurettin Selçuk gibi yüzlerce büyük ismin katkılarıla günümüze gelene kadar en mükemmel șeklini bulmuş bir musikisi vardır. Bu musiki doğal olarak farklı dönemlerde 
gerek șekil, gerek içerik olarak değișik kalıplara bürünmüş, ama her yüzyılda yapısını ve ruhsal zenginliğini güçlendirip çeșitlendirerek Türk toplumunun kültürel kodlarını zamanının ötesine tașımayı bașarmıștır. Tek sesli müzik türünün en mükemmel șekline ulașan Türk Müziği, halkın kültürel hafızasından beslenen "Halk Müziği”, "Türk Halk Müziği” adlarını verdiğimiz tür ile Osmanlı İmparatorluğu'nun seçkin sınıfı tarafından Divan Edebiyatı etkisiyle geliștirilmiș “Türk Müziği”", "Geleneksel Türk Müziği”, “Türk Sanat Müziği”, "Alaturka Müzik" gibi değișik adlarla andığımız türün bütünleșmiș halidir. Toplumsal katmanlara bağlı farklılıklar gösterseler de teknik olarak aynı kökten beslenirler. Her ikisinin de toplumun kültürel hafızasında rolü çok büyük ve önemlidir. Ancak Cumhuriyet'in ilk yıllarında etkisini artıran Batılılașma süreci içinde Batı Müziği takdim edilirken, gerek eğitim alanında, gerek radyo yayınlarında Halk Müziği'nin nispeten korunduğunu ve Türk Müziği'ne mesafeli bir yaklașım gerçekleștiğini görüyoruz. Nitekim 1934-36 yılları arasında radyo yayınlarından Türk Müziği yasaklanırken Halk Müziği yayınının serbest bırakılması bu yaklaşımın bir göstergesidir (Bkz; Ayas, 2014). Bu yaklașım günümüze gelene kadar Türkiye'deki müzik eğitim anlayıșının șekillenmesinde etkili olmuștur. Bunun sonucunda günümüzde toplumda eğitim anlamında tercih edilen ilk müzik türü Batı Müziği olmuş, Halk Müziği her ne kadar Türk Müziğgi'nden daha önde gelse de, her iki türün eğitimine yönelim, çok düşük düzeyde kalmıștır.

Eğitim, bir çok öğenin karșılıklı olarak içinde bulunduğu bir değișim ve gelișim sürecidir. Eğitim kurumları bu görevi önceden hazırlanmış bir program ile gerçekleștirir. Bu anlamda eğitim programları, niteliğin artması ve hedeflere ulașmada temel unsuru oluşturmaktadır. Eğitim programı bir eğitim kurumunun, çocuklar, gençler ve yetișkinler için sağladığı, milli eğitimin ve kurumun amaçlarının gerçekleșmesine dönük tüm faaliyetleri kapsar (Varış, 1996, s. 14)

Türk müzik eğitiminin, Osmanlı Imparatorluğunda Enderûn Mektebi'nin teșkilatlandığı 15 . yüzyıla kadar uzanan köklü bir geçmiși vardır (Uzunçarșıll, 1977, s. 81). Türkiye'de günümüzde uygulamakta olduğumuz müzik öğretim programları ise Islahat Dönemi öncesinde olușmaya başlamıștır. 19 . yüzyılda Batıda meydana gelen sosyal, siyasal ve ekonomik değișmeler, kısa bir süre sonra Osmanlı İmparatorluğu üzerinde de etkilerini göstermiș ve Osmanlı Devleti Avrupa'nın yörüngesine girmiștir (Akkaș, 1997, s. 114-115). Ülkemizde Batıılaşma adı altında öğretim programı veya öğretimin planlanması ise Tanzimat Döneminde (1839-1876) bașlamıștır. Bu durum müzik eğitimine de yansımıștır. "Tanzimat aydınları eski eğitim yöntemlerini kıyasıya eleștirmeye başlar, bir yandan eğitim ve öğretim yöntemlerini tartışırken diğer yandan ders ve programlar ele alınır. "Müzik Dersi" ise 1913 tarihli Geçici Illköğretim Yasasında "Gına" adıyla yer alır." (Akyüz, 1994, s.97).

Osmanlı Maarifi'nin șekillenmeye bașladığı yıllarda müzik dersleri yüzeysel olarak ișlenmiș olsa da müfredatta bu dersin yer alması oldukça önemlidir. On dokuzuncu yüzyılın sonlarına doğru maarif programlarında "gına" ve "mûsikî" bașlıklı iki farklı ders dikkat 
çekmektedir. Gına dersinde daha çok icra eğitimi verilirken mûsikî bașlığı altında nota ve diğer nazari konular ișlenmiștir. Müfredata ilk olarak "gına" ismiyle giren dersler, zaman içinde çeșitlenerek piyano, keman, mûsikî ve teganni adlarıyla okutulmuștur. Müzik derslerinin branș esaslı ders isimleriyle verilmesi oldukça dikkat çekicidir. "Osmanlı müzik eğitimi konusunda ayrıntılı bilgi için bkz.; (Özden, 2020)". Ayrıca bkz; (Ergin, 1977)

\section{Batılılașmanın temelinde, eğitim programlarında yapilan yeni} düzenlemeler bulunmaktadır. Reform hareketleri düșüncesiyle çıkılan bu yolda 1924 yılında yazılan ilkokul müzik programı Türkiye Cumhuriyeti Devleti'nin ilk müzik programıdır. Musiki başlığından sonra sınıflar ve müzik dersinin ișlenișine yönelik açıklamalar içermektedir (Demircioğlu, 2019). Ayrıca bu tarihlerde ilkokul müzik kitapları hakkında detaylı bir raporun hazırlandığını görüyoruz. Cumhuriyetin bu ilk yıllarında Atatürk'ün ilke ve inkîlapları doğrultusunda her alanda olduğu gibi müzik, edebiyat ve sanat alanında tam bir kültürel değişimin yaşandığı söylenebilir. $\mathrm{Bu}$ dönemde gerçekleștirilen yenileșme hareketlerinin Türk müziğine etkisi son derece dikkat çekicidir. Toplumu kültürel anlamda dönüștürmek amaciyla ortaya konan girișimlerden bazıları Darülelhan'da Alaturka müzik şubesinin kapatılması ve Darülelhan'ın Batı müziği eğitimi ağırlıklı olarak yeniden açılması (Özden, 2019, s. 179), Mısır'da düzenlenen Beynelmilel Şark Musikisi Kongresi'ne davet edilen Türk konservatuvarının "Biz Şark musikisiyle meșgul değiliz" diyerek çağrıya duyarsız kalması (1932), TRT Radyosu'nda Türk Müziği'ne yasak getirilmesi ve Alaturka-Alafranga müzik kutuplașmalarının olması (2 Kasım 1934), gazete ve dergilerde Batı müziği enstrümanlarının özendirilmesi ve buna karşılık Türk Müziği enstrümanlarının geriliğin sembolü olarak gösterilmesi, radyo ve halk evlerinin halkı Batı müziğine özendirmek için araç olarak kullanılmasıdır (Deniz, 2017, s.33). Batılılașma hareketlerinin yoğun olduğu bu süreçte Türk müziğinin yasaklandığ dönem ile ilgili, Mustafa Kemal Atatürk'ün șu sözlerine yer vermek yerinde olacaktır:

\footnotetext{
“Ne yazık ki, benim sözlerimi yanlıș anladılar... Ben demek istedim ki bizim seve seve dinlediğimiz Türk bestelerini, onlara da (Avrupalıya) dinletmek çaresi bulunsun, onların tekniği, onların ilmi ile, onların sazlar1... çaresi her ne ise... Türk'ün nağmelerini kaldırıp atalım da sadece garp milletlerinin hazırdan musikisini alıp kendimize mal edelim, yalnız onları dinleyelim demedim. Yanlıș anladılar sözlerimi, ortalığı öyle bir velveleye verdiler ki, ben de bir daha sözünü edemez oldum." (T.C. Kültür ve Turizm Bakanlığı, t.y.)
}

Tanzimat Dönemi’nden günümüze kadar etkisini göstermiș olan Batı eksenli eğitim modelleri sanat eğitiminde kendini fazlasıyla gösterir. Sistem, metodoloji ve kuramsal anlamda Batı eğitiminin birebir aynısının verilmeye çalıșıldığı bu model Türk müziğinde de uygulanmış fakat farklı sistemlere sahip olmaları bakımından aynı etkiyi olușturamamıștır. Cumhuriyet'in sonraki dönemlerinde Batılılașma yolunda Batı müziği örnek alınarak, belirtilen hedeflere uygun müzik yüksekokulları ve konservatuvarlar açılmıştır. Günümüze kadar açılan güzel sanatlar fakülteleri, konservatuvar ve müzik öğretmenliği anabilim dallarının sayısı bir hayli yüksektir. Son yıllarda Türkiye'deki müzik eğitiminde göze çarpan önemli bir gelișme ise güzel sanatlar liselerinin sayısındaki artıștır. 1989 yılında ilki dönemin Milli Eğitim Bakanı Avni Akyol tarafından İstanbul'da 
kurulmuş olan Güzel Sanatlar Liseleri olușum süreci bașlatılmıștır. Güzel Sanatlar Liseleri bugün orta öğretim düzeyindeki müzik eğitiminin en önde gelen eğitim kurumlarıdır. Türkiye'de 1980 sonrası sanat alanında gerçekleștirilmiş en köklü hamlelerden biri olarak değerlendirilebilecek Güzel Sanatlar Liselerinin kuruluş amaçları,16 Haziran 2009 tarihli Resmi Gazete'de yayınlandığı șekliyle, Spor Liseleriyle birleștirilerek Millî Eğitim Bakanlığı yönetmeliğinde șu șekilde sıralanmıștır;

MADDE 6 - (1) Öğrencilerin Türk Millî Eğitiminin genel ve özel amaçları yanı sıra güzel sanatlar ve spor alanlarında;

a. İlgi, istek ve yetenekleri doğrultusunda güzel sanatlar ve spor eğitimi ile ilgili temel bilgi ve beceriler kazanmalarına yönelik eğitim-öğretim görmelerini ve alanlarında başarılı bireyler olarak yetișmelerini,

b. Güzel sanatlar ve sporla ilgili yükseköğretim programlarına hazırlanmalarını,

c. Türk sanat, kültür ve sporuna katkıda bulunan ve bașarıyla temsil eden bireyler olarak yetișmelerini,

d. İş birliği içinde çalıșma ve dayanıșma alıșkanlığı kazanarak takım ruhu ile hareket etmelerini,

e. Alanlarıyla ilgili araștırma yaparak yorum ve uygulama yetkinliğine ulașabilmelerini,

f. Millî ve milletlerarası sanatsal ve sportif faaliyetleri takip ederek bilgi ve kültürlerini geliștirmelerini, g. Spor disiplini ve centilmenliği ile sanatçı duyarlığını benimseyen bireyler olarak yetișmelerini sağlamaktır (Resmî Gazete, 2009, Sayı 27138 )

1989 yılından günümüze gelene kadar Müzik ve Resim olarak iki branșta eğitim veren Güzel Sanatlar Liselerinin sayısı her geçen yıl artmış ve bugün doksan ikiye ulașmıștır. Cumhuriyet sonrası Türkiye'deki müzik eğitiminde sürdürülen Batılılașma politikasına paralel olarak, bugün mevcut Güzel Sanatlar Liselerinin seksen dokuzunda,Batı müziği ekseni üzerinde șekillenmiș müzik eğitimi verilmektedir. Ancak, Güzel Sanatlar Liselerinin 2019 yılında Mesleki ve Teknik Eğitim Genel Müdürlüğüne bağlanmasının ardından, 2020-21 eğitim yılında İstanbul'da üç yeni Güzel Sanatlar Lisesi, Batı Müziği eğitimi olmaksızın, Türk Müziği ve Halk Müziği alanlarında eğitim verecek șekilde öğrenime açılmıștır. Ayrıca daha önce Batı Müziği ağırlıklı eğitim veren İstanbul'daki Bașakșehir Güzel Sanatlar Lisesi'ne Türk Müziği bölümü eklenmiștir. 2020-2021'de yeni açılan Güzel Sanatlar Liseleri'nden ikisine Türk Müziği'nin tarihe mal olmuş bestekârlarından Itrî ve Abdülkadir Meragî'nin isimleri verilmiștir. Türk Müziği bölümü eklenen Bașakșehir Güzel Sanatlar Lisesi'nin adı da diğer büyük bestekâr Hammamizade İsmail Dede Efendi'den esinlenerek İsmail Dede Efendi Güzel Sanatlar Lisesi olarak değiștirilmiștir. Ayrıca yapılan protokollerle Beșiktaș Itrî Güzel Sanatlar Lisesi İstanbul Üniversitesi'nin, Pendik Abdülkadir Meragî Güzel Sanatlar Lisesi Marmara Üniversitesi'nin, Başakșehir İsmail Dede Efendi Güzel Sanatlar Lisesi ise İstanbul Teknik Üniversitesi'nin himayesi altına alınmıștır. Üniversitelerin himayesi altına alınan söz konusu üç 
Güzel Sanatlar Lisesinde dört yıllık eğitim sürecinin başına İngilizce Hazırlık sınıfı eklenmiștir. 2020-21 öğretim yılında yeni açılan Atakent Güzel Sanatlar Lisesine Türk Müziği'nin yașayan usta ses sanatçısı ve bestekârı Prof. Dr. Alâeddin Yavașca'nın ismi verilmiștir. Ancak Atakent Güzel Sanatlar Lisesi bu ismi almadan önce, kuruluş așamasında Batı Müziği eğitimi vermek üzere planlanmıș bir okuldur. Yine 2020-21 öğretim yılında açılan Bağcılar Hikmet Barutçugil Güzel Sanatlar Lisesi, Batı Müziği eğitimi olmaksızın Türk Müziği ve Halk Müziği eğitimi vermek üzere öğrenime bașlamıștır.

İstanbul'da yeni açılan üç Güzel Sanatlar Lisesinin Türk Müziği ve Halk Müziği alanında eğitim vermeye başlaması, ayrıca mevcut bir Güzel Sanatlar Lisesine Türk Müziği bölümü eklenmesi tüm Güzel Sanatlar Liselerindeki ders dağılım șemasında büyük değișiklik yapmamıștır. Bu okulların sadece Türk Müziği ve Halk Müziği alanında eğitim vermek amacıyla kurulmalarına rağmen, tüm Güzel Sanatlar Liselerinde kullanılan ve Batı Müziği derslerinin yoğunlukta olduğu öğretim programı uygulanmaya devam etmektedir. Mevcut durumda doksan iki okuldan seksen dokuzunda Batı Müziği eğitimi verilmekte, yeni açılan üç okul, sadece Türk Müziği ve Halk Müziği eğitimi vermektedir. Doksan iki okulun yeni açılanlar dışında onunda Halk Müziği, dördünde ise Türk Müziği bölümü mevcuttur. Türk Müziği bölümü bulunan okullar ìstanbul Avni Akyol Güzel Sanatlar Lisesi, Bursa Zeki Müren Güzel Sanatlar Lisesi, Bașakșehir İsmail Dede Efendi Güzel Sanatlar Lisesi ve Kahramanmaraş Güzel Sanatlar Lisesi'dir. Halk Müziği bölümü bulunan okullar ise Ankara Mimar Sinan Güzel
Sanatlar Lisesi, Batman TOBB Güzel Sanatlar Lisesi, Bașakșehir İsmail Dede Efendi Güzel Sanatlar Lisesi, Bakırköy Güzel Sanatlar Lisesi, İzmir Ișılay Saygın Güzel Sanatlar Lisesi, Kahramanmaraș Güzel Sanatlar Lisesi, Kırıkkale Güzel Sanatlar Lisesi, Kırșehir Neșet Ertaș Güzel Sanatlar Lisesi, Kütahya Ahmet Yakupoğlu Güzel Sanatlar Lisesi ve Sivas Muzaffer Sarısözen Güzel Sanatlar Lisesi'dir.

Her yıl yapılan yetenek sinavı ile öğrenci kabul eden Güzel Sanatlar Liselerinde, Millî Eğitim Bakanlığı tarafından hazırlanan öğretim programları kullanılmaktadır. Bu öğretim programlarında genel kültür derslerinin yanı sıra ilgili bölümlerin alan dersleri yer almaktadır.

Milli Eğitim Temel Yasasının 33. maddesine göre kurulan Güzel Sanatlar Liselerinin müzik bölümlerinde uygulanan ve 19.02.2018 tarihinde Talim ve Terbiye Kurulu Bașkanlığı tarafından yayımlanan müzik öğretim programı kapsamında piyano dersi dört yıl süresince zorunlu olarak okutulan dersler kapsamındadır.2017 - 18 öğretim yılında Batı Müziği eğitimi alan öğrencilere Halk Müziği enstrümanı olan bağlamayı zorunlu ders çerçevesinde öğrenme kuralı getirilmiștir. Buna karșılıkTürk müziği enstrümanlarına yönelik zorunlu ders söz konusu olmamıștır. Oysa, müzik eğitiminin temel boyutlarından biri olan çalgı eğitiminin yapılmadığı durumlarda, müzik eğitimi ya eksik, ya yetersiz ya da yeterince sağlam ve tutarlı olmaz (Tanriverdi, 1997, s.8).

Güzel Sanatlar Lisesi'ne yeni başlayan öğrencilere yönelik 9. sınıf müzik öğretim programına baktığımızda Türk Müziği ve 
Batı Müziği eğitiminde haftada ikișer saat teorik ders verildiğini görmekteyiz. Ancak müzikle yeni tanıșan öğrenciler ek olarak her hafta bir saat zorunlu piyano dersi almaya başlamaktadırlar. İlk yıl Türk Müziği ya da Halk Müziği enstrüman dersi programa konmamıștır. Zorunlu piyano dersi almaya bașlayan öğrenciler çoğunlukla ilk yıl programda bulunan seçmeli enstrüman derslerinde de, aldıkları eğitime paralel olarak bir bașka Batı Müziği enstrümanını tercih etmektedirler. Diğer yandan Güzel Sanatlar Liselerinde öğretmenlik yapanların büyük çoğunluğunun, üniversitelerin eğitim fakültelerinin müzik eğitimi bölümünden mezun olan ve eğitim süreci boyunca Batı müziği eğitimi alan kișilerden olușması, Türk Müziği alanında sağlıklı bir eğitimi imkansız kılmakta, ayrıca Güzel Sanatlar Liselerine yeni bașlayan gençlerin doğal olarak Batı Müziğine yönlendirilmesine yol açmaktadır. Zira "ülkemizde müzik öğretmeni olabilmek için eğitim fakültelerinde yer alan güzel sanatlar eğitimi bölümünün müzik öğretmenliği bölümünden mezun olmak gerekiyor". Türk Müziği eğitimi veren konservatuvarlardan mezun olanların öğretmenlik yapmaları için ise orta öğretim alan öğretmenliği tezsiz yüksek lisans programını ya da pedagojik formasyon programını tamamlayarak başvurmaları istenmektedir. Bu uzun süreç genellikle konservatuvar mezunlarının bașka alanları tercih etmelerine yol açmaktadır. Eğitim Fakültelerindeki müzik öğretmenliği lisans bölümlerinde ise Batı Müziği ağırlıklı bir eğitim verilmektedir. Güzel Sanatlar Liselerinde müzik öğretmeni olanlar, bu alt yapı üzerinden öğrencilerini yönlendirmektedirler.
Tam bu noktada "Türk musikisi eğitimi neden gereklidir?" sorusuna verdiği cevapta Varol'un sözlerine dikkat çekmekte fayda vardır. Varol, Türk çocuğunun Türk ses sistemine uygun bir müziği öğrenmesi, hiç olmazsa ana hatlarıyla Bach'ın hayatını bildiği kadar Dede Efendi'nin de hayatını bilmesi, Haydn'ın hayatını, doğduğu yeri, yașadığı ili ve verdiği eserleri bildiği kadar Itri'nin de eserlerini ve yașadığı devri bilmesi gerektiğini vurgulamıștır (Varol,1988, s.37).

\section{Araștırmanın Amacı}

$\mathrm{Bu}$ araștırma ile Güzel Sanatlar Liselerinde uygulanan müzik öğretim programındaki Türk Müziği, Halk Müziği ve Batı Müziği türlerindeki haftalık ders saati planlamalarının müzik bölümündeki öğrenci sayılarına yansımasının ortaya konulması amaçlanmıștır. Bu çalıșmanın veriler eșliğinde ortaya koyulmasının alana katkı sağlayacağı düșünülmektedir.

\section{Araștırmanın Önemi}

Müzik öğretimi ile ülke bazında bireylere kazandırılmak istenen birçok davranıș ve bilginin yanında kültürel miras aktarımını gerçekleștirmek, Atatürk'ün Türk müziğinin gelișmesine ilișkin görüșlerini kavratmak ve Atatürk ilke ve inkılâplarına gönülden bağlı, kültürlü bireyler olarak yetișmelerini sağlamak, Milli Eğitim Bakanlığı müzik öğretim programı genel amaçları arasında yer almaktadır (Aksu, 2015, s.62)

Bu çerçevede, Güzel Sanatlar Liselerinde uygulanan müzik öğretim programına yerleștirilmiş Türk Müziği, Halk Müziği ve Batı müziği türlerindeki haftalık ders saati planlamalarının, müzik bölümündeki öğrenci sayılarına yansıması hakkında bilgi sahibi olmak, bize müzik 
öğretim programlarının hazırlanması ve amaçlanan hedeflere uygun olması konusunda katkı sağlayacaktır. Zira, ülkemizdeki Güzel Sanatlar Liselerinde uygulanan müzik öğretim programının eksik yönlerini gidermek adına yeni stratejiler geliștirmek, Milli Eğitim Bakanlığı'nın belirlediği amaçların gerçekleștirilmesi açısından büyük önem arz etmektedir.

\section{Metodoloji}

\section{Materyal ve Yöntem}

Araștırma, kaynak taramasına, Milli Eğitim Bakanlığı Öğrenci İșleri Daire Bașkanlığından alınan Güzel Sanatlar Liseleri öğrenci verilerine ve 19.02.2018 tarihinde Talim ve Terbiye Kurulu Bașkanlığı tarafından yayımlanan Güzel Sanatlar Liselerinde uygulanan müzik öğretim programı kapsamındaki haftalık ders programına dayanmaktadır.

Güzel Sanatlar Liseleri öğrenci verileri ve Güzel Sanatlar Liselerinde uygulanan müzik öğretim programı araștırmanın ana materyalidir. İkincil materyal olarak çeșitli dergiler, kitaplar, raporlar vb. kaynaklar kullanılmıș, internet ortamındaki kaynaklar taranmıștır.

İnceleme türü olarak araștırma modeli tercih edilmiștir. "Inceleme türü araștırma modelinde, problemin tanımlanması, keșfedilmesi, problemin kesin olarak saptanması, geçerli değișkenlerin ve bunlar arasındaki ilișkilerin belirlenmesi söz konusudur." (İslamoğlu, Alnıaçık, 2014). Öyle ki, araștırmaya konu olan olay, birey ya da nesne, kendi koșulları içinde ve var olduğu gibi tanımlanmaya çalıșılır. Onları herhangi bir șekilde değiștirme, etkileme çabası gösterilemez. Bilinmek istenen şey vardır ve oradadır. Önemli olan, ona uygun biçimde "gözleyip" belirleyebilmektir (Karasar, 2005, 77).

\section{Araștirma Modeli}

Çalıșmamızda uygulanan model, karșılaștırmalı araștırma modelidir. Karșılaștırmalı araștırma modeli, en az iki değișkenden olușan durumlar arasında karșılaștırmaların yapıldığı çalıșmalardır. Konu ile ilgili veriler toplanarak verilerin analiz edilmesi amaçlanmaktadır. Karșılaștırmalı araștırma modeli yönteminin kullanıldığı bu çalışmada, veri toplamak amacıyla Milli Eğitim Bakanlığı Öğrenci İşleri Daire Bașkanlığından alınan Güzel Sanatlar Liseleri öğrenci verileri ve 19.02.2018 tarihinde Talim ve Terbiye Kurulu Bașkanlığı tarafından yayımlanan Güzel Sanatlar Liselerinde uygulanan müzik öğretim programı haftalık ders programı kullanılmıștır.

\section{Bulgular ve Analiz}

Araștırmanın genel amacı doğrultusunda, Güzel Sanatlar Liselerinde uygulanan müzik öğretim programının haftalık planı incelendiğinde, öncelikle dokuzuncu sınıflarda zorunlu dersler çerçevesinde kültür derslerinin ağırlıkta olduğu, müzik derslerinin toplam saatinin altı ile sınırlandığı görülmektedir. Beș seçmeli ders ve rehberlik dersinin hesaplanmasıyla birlikte haftalık kırk saat olan derslerin dağılımlarına bakıldığında, Batı müziği derslerinin haftada üç ders saati ile toplam ders saati içerisindeki oranının \%7.5 olduğu, Türk müziği derslerinin haftada iki ders saati ile toplam ders saati içerisindeki oranının \%5 olduğu belirlenmiștir (bkz. Tablo-1). Ayrıca seçime bağlı olduğu için tabloda Batı Müziği ya da Türk Müziği içinde gösterilemeyen ve Diğer Dersler arasında bulunan Çalgı Eğitimi dersinin, mevcut 
sistemde gerek ana branșları genellikle Batı Müziği sazları olan öğretmenlerin yönlendirmesi, gerek zorunlu piyano dersinin etkisiyle öğrenciler tarafından Batı Müziği enstrümanlarından biri olarak seçildiği bölümlere göre öğrenci sayılarından anlaşılmaktadır. Halk Müziği ise dokuzuncu sınıfta ne teorik bilgi ne de çalgı eğitimi alanında ders olarak programa yerleștirilmemiștir. Bu çerçevede dokuzuncu sınıfa bașlayan öğrenciler yıl boyunca, genel olarak öğrenim hayatlarının devamında Batı Müziği'ni tercih edecek alt yapıya sahip hale gelmektedirler.
Onuncu siniflarda okutulan derslerin haftalık planlamasına bakıldığında öncelikle müzik eğitimi derslerinin arttığı gözlenmektedir. Bu çerçevede Batı Müziği derslerinin haftada yedi ders saati ile toplam ders saati içerisindeki oranının \%17.5 olduğu, Türk Müziği derslerinin haftada iki ders saati ile toplam ders saati içerisindeki oranının \%5 olduğu, Halk Müziği derslerinin ise haftada bir ders saati ile \%2.5 olduğu görülmüștür. Onuncu sınıfta seçmeli derslere yer verilmemiș, tüm dersler zorunlu ders olarak planlanmıștır. (bkz. Tablo-2)

Tablo-1. 9. Sınıf Müzik Derslerinin Haftalık Ders Saatine Oranı

\begin{tabular}{|l|c|c|}
\hline \multicolumn{2}{|c|}{ 9. Sınıf Müzik Derslerinin Haftalık Ders Saatine Oranı } \\
\hline Dersler & Haftalık Ders Saati & \% \\
\hline Diğer Dersler & 35 & 87,5 \\
\hline Batı Müziği & 3 & 7,5 \\
\hline Türk Müziği & 2 & 5 \\
\hline Toplam & 40 & 100 \\
\hline
\end{tabular}

Tablo-2.10. Sınıf Müzik Derslerinin Haftalık Ders Saatine Oranı

\begin{tabular}{|l|c|c|}
\hline \multicolumn{3}{|c|}{ 10. Sınıf Müzik Derslerinin Haftalık Ders Saatine Oranı } \\
\hline Dersler & Haftalık Ders Saati & \% \\
\hline Diğer Dersler & 30 & 75 \\
\hline Batı Müziği & 7 & 17.5 \\
\hline Türk Müziği & 2 & 5 \\
\hline Halk Müziği & 1 & 2.5 \\
\hline Toplam & 40 & 100 \\
\hline
\end{tabular}


On birinci sinifta okutulan derslerin planlamasında kültür dersleri azalmakta, müzik derslerinin sayısı artmaktadır. Seçmeli ders sayısı haftada dört, rehberlik dersi haftada bir, kültür derslerinin sayısı haftada on beș saat olarak belirlenmiștir. Kalan haftalık yirmi saatlik ders dilimi müziğe ayrılmıștır. Müzik derslerinin oranına bakınca Batı Müziği derslerinin haftada on bir ders saati ile \%27.5, Halk Müziği derslerinin yedi ders saati ile \%17.5, Türk Dünyası Müzikleri adıyla Türkiye dıșında icra edilen otantik müziklerin öğretildiği dersin iki ders saati ile \%5 olduğu görülmektedir. On birinci sınıfta Türk Müziği dersi programa konmamıștır. On birinci sınıfta haftada dört saat verilen Çalgı Toplulukları derslerinde Batı Müziği orkestraları olușturulmakta ve Türk Müziği ile Halk Müziği enstrüman ve repertuvarları enstrümanlarıyla kıyaslanmayacak kadar az oranda Türk Müziği ve Halk Müziği enstrümanlarına ayrılmıștır. Bu nedenle Batı Müziği kapsamı içinde gösterilmiștir. Öte yandan Türk Dünyası Müzikleri dersinin içeriğinde yer alan müzikler, Türk Müziği'nin makamsal yapısı içine alınıp Türk Müziği dersi olarak değerlendirilemeyecek kadar farklıdır. Dolayısıyla iki saatlik bu ders ayrı bir başlık altında değerlendirilmiștir.

On ikinci sınıfta okutulan derslerin programında kültür dersleri daha da azaltılarak haftada on üç saate indirilmiștir. Rehberlik saati ve üç saat seçmeli dersleri bu sayıya ekleyip toplam kırk saatlik haftalık ders sayısından çıkardığımızda, müzik ders programının daha önceki üç yıla göre arttırıldığını ve toplamda yirmi üç saate

Tablo-3.11. Sınıf Müzik Derslerinin Haftalık Ders Saatine Oranı

\begin{tabular}{|l|c|c|}
\hline \multicolumn{3}{|c|}{ 11. Sınıf Müzik Derslerinin Haftalık Ders Saatine Oranı } \\
\hline Dersler & Haftalık Ders Saati & $\%$ \\
\hline Diğer Dersler & 20 & 50 \\
\hline Batı Müziği & 11 & 27.5 .5 \\
\hline Türk Müziği & 0 & 0 \\
\hline Halk Müziği & 7 & 17.5 \\
\hline Türk Dünyası Müzikleri & 2 & 5 \\
\hline Toplam & 40 & 100 \\
\hline
\end{tabular}

konu dışı kalmaktadır. Dolayısıyla Çalgı Toplulukları dersi, oranlar hesaplanırken Batı Müziği kapsamında ele alınmıștır. Çalgı Eğitimi dersi ise Türk Müziği ve Halk Müziği bölümü bulunmayan Güzel Sanatlar Liselerinde tamamen, bu bölümlere sahip okullarda da Türk Müziği ve Halk Müziği öğrenci sayılarından anlașılacağı gibi, Batı Müziği çıktığını görmekteyiz. Müzik derslerinin çeșitlenmesine bağlı olarak içerikleri incelediğimizde iki saatlik Drama ve iki saatlik Bilișim Destekli Müzik derslerinin Batı Müziği kapsamına girdiğini görmekteyiz. Müzik Kültürü dersinde genel müzik eğitiminden yola çıkarak hem Batı Müziği hem Türk Müziği konu edilmektedir. Oranları belirlerken iki 
saatlik Müzik Kültürü dersinin bir saati Batı Müziği, bir saati Türk Müziği olarak hesaplanmıștır. Aynı șekilde iki saatlik Türk ve Batı Müziği Tarihi dersi de iki farklı tür müziğin sayısal verileri arasında birer saat olarak paylaștırılmıștır. $\mathrm{Bu}$ çerçevede müzik derslerinin yoğunlaștırıldığı Güzel Sanatlar Lisesi son sınıftaki müzik türü dağılımı șöyle olmaktadır: Batı Müziği dersleri on dört ders saati ile \%35, Halk Müziği dersleri üç ders saati ile \%7.5, Türk Müziği dersleri altı ders saati ile $\% 15$.
Tablo 1-2-3-4'teki haftalık ders dağılımlarının müzik alanı öğrenci sayılarına yansıması şöyledir: Türkiye genelinde 2020-21 öğretim yılında Güzel Sanatlar Liselerinin sınavını kazanıp hazırlık sınıfı olmayan bir okula yerleșmiş müzik öğrencisi sayısı iki bin üç yüz yirmi üç olmuștur. Bu öğrencilerin müzik türlerini tercih etmelerine bağlı olarak dağılımlarına bakıldığında, Batı müziğiniiki bin iki yüz yirmi iki öğrencinin, Halk Müziğini seksen dokuz öğrencinin, Türk Müziği'ni ise on iki

Tablo-4.12. Sınıf Müzik Derslerinin Haftalık Ders Saatine Oranı

\begin{tabular}{|l|c|c|}
\hline \multicolumn{3}{|c|}{ 12. Sınıf Müzik Derslerinin Haftalık Ders Saatine Oranı } \\
\hline Dersler & Haftalık Ders Saati & \% \\
\hline Diğer Dersler & 17 & 42.5 \\
\hline Batı Müziği & 14 & 35 \\
\hline Türk Müziği & 6 & 15 \\
\hline Halk Müziği & 3 & 7.5 \\
\hline
\end{tabular}

Tablo-5.Güzel Sanatlar Lise 9. Sınıf Müzik Öğrencisi Dağılımı (2020-21)

\begin{tabular}{|l|c|c|}
\hline Hazırlık Olmayan GSL 9. Sınıf Müzik Öğrenci Dağılımı ((2020-21) \\
\hline Müzik Alanı & Öğrenci Sayısı & Yüzdelik (\%) \\
\hline Batı Müziği & 2222 & 95,7 \\
\hline Türk Halk Müziği & 89 & 3,8 \\
\hline Türk Müziği & 12 & 0,5 \\
\hline Toplam Ö̆ğrenci Sayısı & 2323 & 100 \\
\hline
\end{tabular}

Tablo-6.Güzel Sanatlar Hazırlık ve 9. Sınıf Müzik Öğrencisi Dağılımı (2020-21)

\begin{tabular}{|l|c|c|}
\hline 2020-21 GSL Hazırlık ve 9. Sınıf Müzik Öğrencisi Dağılımı \\
\hline Müzik Alanı & Öğrenci Sayısı & Yüzdelik (\%) \\
\hline Batı Müziği & 2251 & 93.1 \\
\hline Türk Halk Müziği & 114 & 4.8 \\
\hline Türk Müziği & 51 & 2.1 \\
\hline Toplam Ö̆ğrenci Sayısı & 2416 & 100 \\
\hline
\end{tabular}


öğrencinin seçtiği görülmektedir. Batı Müziğini tercih eden öğrencilerin toplam dokuzuncu sınıf müzik öğrencisi sayısına oranı \%95.7, Halk Müziğini tercih eden öğrencilerin toplam dokuzuncu sınıf müzik öğrencisi sayısına oranı \%3.8, Türk Müziğini tercih eden öğrencilerin toplam dokuzuncu sınıf müzik öğrencisi sayısına oranı ise \%0.5 olmuștur(bkz. Tablo-5).

Tabloda yer alan on iki Türk Müziği öğrencisinin sadece Bursa Zeki Müren Güzel Sanatlar Lisesi'ne kayıt olan öğrenciler olması, Türk Müziği bölümü bulunan diğer okulların 2020-21 öğretim yılında bu bölümleri için öğrenci kaydetmemiş olmaları bir bașka ilgi çekici noktadır. Halk Müziği bölümü bulunan Güzel Sanatlar Liselerinden Buca Ișılay Saygın Güzel Sanatlar Lisesi ve Kahramanmaraș Güzel Sanatlar Lisesi 2020-21 öğretim yılında bu bölümlerine öğrenci kaydetmemiștir.

2020-21 öğretim yılında açılan ve şu anda hazırlık sınıfında okuyan öğrencileri bölümlerine göre Batı Müziği, Türk Müziği ve Halk Müziği öğrencisi șeklinde hesaba katarak dokuzuncu sinıfların sayısal verilerini incelediğimizde, genel öğrenci sayısının iki bin dört yüz on altıya ulaștığı, Batı Müziği öğrenci sayısının iki bin iki yüz elli bir, Halk Müziği öğrenci sayısının yüz on dört, Türk Müziği öğrenci sayısının ise elli bir olduğu görülmektedir. Hazırlık sınıfı ile Batı Müziği eğitimi alan burada tabloya dahil edilen öğrenciler sadece ITÜ himayesine giren Başakșehir İsmail Dede Efendi Güzel Sanatlar Lisesi'nde bulunmaktadır. Hazırlık sınıfı bulunan ve öğrencileri buradaki tabloya dahil edilen diğer iki okul (Itri GSL ve Abdülkadir Meragi GSL) sadece Türk Müziği ve Halk Müziği eğitimi vermek üzere açılmıștır. Buna göre oranlar değișmiș, Batı Müziği bölümleri \%93.1, Halk Müziği bölümleri \%4.8 ve Türk Müziği bölümleri \%2.1 oranında öğrenci sayısına ulașmıștır (bkz. Tablo-6). Bu değișim, sadece Türk Müziği ve Halk Müziği eğitimi veren okullar açılmasının özellikle Türk Müziği alanında öğrenci yetiștirilmesine \%1.6 oranında pozitif etki yaptığını göstermektedir. Bu noktada, yeni açılan ve Marmara Üniversitesi himayesinde faaliyet göstermeye bașlayan Abdülkadir Meragi Güzel Sanatlar Lisesi Müzik Hazırlık Sınıfına sadece Halk Müziği öğrencisi alındığını, Türk Müziği öğrencisi kaydı yapılmadığını belirtmek gerekir. Aynı șekilde hazırlık sınıfı olmadan yeni açılan ve sadece Türk Müziği ve Halk Müziği bölümleri bulunan Hikmet Barutçugil Güzel Sanatlar Lisesi'nin de Türk Müziği bölümüne öğrenci kaydı yapılmamıștır. Bunun gerekçesinin, açılıș takviminin gerekli tanıtımları yapmak için geç kalması olduğu tahmin edilmektedir. Yetenek sınavı ile öğrenci alan okullara bașvuru e-kılavuzu 2020'de İstanbul'da tematik olarak açılan söz konusu yeni Güzel Sanatlar Liselerinin adları yer alamamıștır.

Onuncu sinıflarda okuyan müzik öğrencilerinin dağılımlarına bakıldığında, Batı Müziği öğrencilerinin, bin dokuz yüz altmıș ile toplam onuncu sınıf müzik öğrencisi sayısına oranının \% 94.1, Halk Müziği öğrencilerinin yüz beș ile toplam onuncu sınıf müzik öğrencisi sayısına oranının \%5 ve Türk Müziği öğrencilerinin on dokuz ile toplam onuncu sınıf müzik öğrencisi sayısına oranının \% 0.9 olduğu saptanmıștır (bkz. Tablo-7)

On birinci sınıflarda okuyan müzik öğrencilerinin dağılımlarına bakıldığında, Batı Müziği öğrencilerinin, bin altı yüz seksen beș ile toplam on birinci sınıf 
müzik öğrencisi sayısına oranının \%94.3, On ikinci sınıflarda okuyan müzik Halk Müziği öğrencilerinin altmıș iki ile öğrencilerinin dağılımlarınabakıldığında, toplam on birinci sınıf müzik öğrencisi Batı Müziği öğrencilerinin, bin beș yüz sayısına oranının \%3.5 ve Türk Müziği altmıș dört ile toplam on ikinci sınıf ögrrencilerinin otuz dokuz ile toplam müzik öğrencisi sayısına oranının \%95.5, on birinci sınıf müzik öğrencisi sayısına Halk Müziği öğrencilerinin altmış altı ile oranının \%2.2 olduğu saptanmıștır (bkz. toplam on ikinci sınıf müzik öğrencisi Tablo-8) sayısına oranının \%4 ve Türk Müziği

Tablo-7.Güzel Sanatlar Lise 10. Sınıf Müzik Öğrencisi Dağılımı

\begin{tabular}{|l|c|c|}
\hline \multicolumn{3}{|c|}{ Güzel Sanatlar Lise 10. Sınıf Müzik Ö̆̆grenci Dağılımı } \\
\hline Müzik Alanı & Öğrenci Sayısı & Yüzdelik (\%) \\
\hline Batı Müziği & 1960 & 94,1 \\
\hline Türk Halk Müziği & 105 & 5 \\
\hline Türk Müziği & 19 & 0,9 \\
\hline Toplam Öğrenci & 2084 & 100 \\
\hline
\end{tabular}

Tablo-8.Güzel Sanatlar Lise 11. Sınıf Müzik Öğrencisi Dağılımı

\begin{tabular}{|l|c|c|}
\hline \multicolumn{3}{|c|}{ Güzel Sanatlar Lise 11. Sınıf Müzik Ö̆̆grenci Dağılımı } \\
\hline Müzik Alanı & Öğrenci Sayısı & Yüzdelik (\%) \\
\hline Batı Müziği & 1685 & 94.3 \\
\hline Türk Halk Müziği & 62 & 3.5 \\
\hline Türk Müziği & 39 & 2.2 \\
\hline Toplam Öğrenci & 1786 & 100 \\
\hline
\end{tabular}

Tablo-9.Güzel Sanatlar Lise 12. Sınıf Müzik Öğrencisi Dağılımı

\begin{tabular}{|l|c|c|}
\hline \multicolumn{3}{|c|}{ Güzel Sanatlar Lise 12. Sınıf Müzik Öğrenci Dağılımı } \\
\hline Müzik Alanı & Öğrenci Sayısı & Yüzdelik (\%) \\
\hline Batı Müziği & 1564 & 95.5 \\
\hline Türk Halk Müziği & 66 & 4 \\
\hline Türk Müziği & 9 & 0.5 \\
\hline Toplam Öğrenci & 1639 & 100 \\
\hline
\end{tabular}


Türkiye'deki güzel sanatlar liselerinin müzik dersi öğretim programlarının öğrenci alan seçimi üzerindeki etkileri üzerine bir araștırma

Tablo-10.Güzel Sanatlar Liseleri toplam müzik öğrencisi dağılımı

\begin{tabular}{|l|c|c|}
\hline \multicolumn{3}{|c|}{ Güzel Sanatlar LiseleriToplam Müzik Öğrencisi Dağılımı (2020-21) } \\
\hline Müzik Alanı & Öğrenci Sayısı & Yüzdelik (\%) \\
\hline Batı Müziği & 7460 & 94,1 \\
\hline Türk Halk Müziği & 347 & 4,4 \\
\hline Türk Müziği & 118 & 1,5 \\
\hline Toplam Öğrenci & 7925 & 100 \\
\hline
\end{tabular}

öğrencilerinin dokuz ile toplam on ikinci sınıf müzik öğrencisi sayısına oranının \% 0.5 olduğu saptanmıștır (bkz. Tablo-9)

Güzel Sanatlar Liselerinde okuyan müzik öğrencilerinin

(Hazırlık-9-10-11-12. sınıflar) toplam sayısının müzik türlerine göre dağılımlarına bakıldığında, yedi bin dört yüz altmıș ile Batı Müziği öğrencilerinin toplam müzik öğrencisi sayısına oranının \%94.1, üç yüz kırk yedi ile Halk Müziği öğrencilerinin toplam müzik öğrencisi sayısına oranının \%4.4 ve yüz on sekiz ile Türk Müziği öğrencilerinin toplam müzik öğrenci sayısına oranının \%1.5 olduğu belirlenmiștir (bkz. Tablo-10)

Tüm bu veriler ıșığında, Batı müziği derslerinin programda yüksek orana sahip olmasının bir sonucu olarak, toplam öğrenci sayısındaki Batı Müziği öğrencilerinin yüzdelik oranının da yüksek olduğu belirlenmiștir. Güzel Sanatlar Liselerinde uygulanan müzik öğretim programı haftalık ders programı Tablo 11'de verilmiștir.

Güzel Sanatlar Liselerinin müzik eğitim programına dayalı haftalık ders programlarının Batı müziği ağırlıklı olarak șekillendirilmesi, okula girdikten sonra yapmak zorunda oldukları müzik türü seçiminde Batı Müziği'ni tercih eden öğrenci sayısını pozitif yönde etkilemektedir. 2020-21 verilerine göre Güzel Sanatlar Liseleri'ndeki toplam yedi bin dokuz yüz yirmi beș müzik öğrencisinin yedi bin dört yüz altmıșı yani \%94.1'i Batı Müziği öğrencisi olmayı tercih etmiștir. Halk Müziği'ni tercih eden toplam üç yüz kırk yedi öğrenci tüm müzik öğrencilerinin \%4.4'ünü olușturmaktadır. Türk Müziği'ni tercih eden yüz on sekiz öğrenci ise tüm müzik öğrencilerinin \%1.5'idir. 2020 - 21 eğitim yılında mevcut doksan iki Güzel Sanatlar Lisesi içinde Batı Müziği eğitimi yanında Türk Müziği bölümü olan dört okuldan sadece bir tanesinin Türk Müziği bölümüne yeni öğrenci almış olması diğerlerinde yeni kayıt yapılmaması ise daha da düșündürücüdür. Bu konunun paralelinde Batı Müziği eğitimi yanında Halk Müziği bölümü bulunan on okuldan iki tanesinin de 2020-21 yılında yeni Halk Müziği öğrencisi kayıt etmemiş olduğu görülmektedir. Bunlara mukabil Milli Eğitim Bakanlığı'nın bu yıl tematik anlamda sadece Türk Müziği ve Halk Müziği eğitimi vermek üzere üç yeni okul açmış olmasının toplam Türk Müziği ve Halk Müziği öğrenci sayısına pozitif etkisi olmuștur. Hazırlık sınıfına kayıt olarak Türk Müziği eğitimine yönelmek isteyen 
otuz dokuz öğrenci ile toplam Türk Müziği öğrencisi sayısı on ikiden elli bire çıkmıș, hazırlık sınıfına kayıt olarak Halk Müziği eğitimine yönelmek isteyen yirmi beș öğrenci ile toplam Halk Müziği öğrencisi sayısı seksen dokuzdan yüz on dörde çıkmıștır. Bu okulların açılmasıyla birlikte özellikle Türk Müziği'ne yönelik talep artışı dikkat çekicidir. Tematik nitelikteki Türk Müziği ve Halk Müziği eğitimi veren üç okulun açılış tarihleri itibarıyla planlamaya dahil olamamalarından dolayı Yetenek Sınavı ile Öğrenci Alan Okullara Bașvuru E-kılavuzu 2020'de yer alamamıș olmaları, Türk Müziği ve Halk Müziği öğrenci sayılarının artıșındaki ivmenin istenen düzeye ulașamadığının bir göstergesidir. Bu okulların, Yetenek Sınavı ile Öğrenci Alan Okullara Bașvuru E-kılavuzunda yer almalarıyla birlikte, gelecek yıllarda öğrenci sayılarının daha da artacağı öngörülmektedir.

\section{Sonuç}

Son yirmi yıldan beri güzel sanatlar fakülteleri, konservatuvar ve müzik öğretmenliği anabilim dallarının sayısı giderek artmaktadır. Bununla birlikte güzel sanatlar liselerinin sayısında da ciddi bir artış görülmektedir. Güzel Sanatlar Liselerinin kuruluș amaçlarına uygun olarak Türk toplumunun kültürel ve tarihsel değerlerini müzik aracılığıyla gelecek nesillere taşımak için lazım olan eğitim çalıșmalarının arttırılması ve mevcut sistemin yeniden șekillendirilmesi eldeki veriler ışığında önemli bir gerekliliktir. Türkiye'deki Türk Müziği eğitimi veren konservatuvarlardan mezun olanların, mezuniyet sonrasında Türk Müziği ve Halk Müziği branșlarında öğretmen olarak Güzel Sanatlar Liselerine bașvurabilmelerinin yolunun açılması, bu imkanın açılmasına bağı olarak özellikle çalgı eğitimi konusunda zorunlu ders olarak okutulan piyano ve bağlama derslerinin yanında diğer Batı Müziği enstrümanları kadar Türk Müziği ve Halk Müziği enstrüman eğitimine yer verilmesi, Güzel Sanatlar Liselerindeki müzik öğrencilerinin müzik türü seçimlerinde daha dengeli bir dağılımın ortaya çıkmasını sağlayacaktır. Bu noktada enstrüman eğitiminin müzik eğitiminde vazgeçilmez bir rolü olduğunu vurgulamak lazımdır. Elbette Eğitim Fakültelerindeki Müzik Öğretmenliği bölümünün ders programının Batı Müziği ağırlıklı olmaktan çıkarılarak, bu okullarda her üç müzik türüne yönelik ayrı branșlarla öğretmen yetiștirilmesi, söz konusu dengesizliğin çözümünü çok daha kolaylaştıracaktır. Bunların ötesinde bir milli politika olarak kendi öz müziğimizin değerinin anlatılması, Batı Müziği'nin çokseslilik anlamında ulaștığı evrensel değerin tekseslilikte kendi müziğimizde de yer aldığının toplumumuzun her sosyal katmanına ifade edilmesi ve devlet kurumları bünyesinde faaliyet gösteren Türk Müziği ve Halk Müziği sanatçılarının organize edilerek bu anlamdaki toplumsal algıyı güçlendirecek çalıșmalar yapmalarının sağlanması, orta ve uzun vadede, müzik eğitimimizdeki Batı Müziği yönelimli yaklaşımın değișmesini sağlayacaktır. $\mathrm{Bu}$ anlamda çalıșacak bürokratik kadroların müzik eğitimine sahip bireylerden olușması ise yöntemlerin belirlenmesinde büyük öneme sahiptir. Türk Müziği yüzlerce yıl öncesinden günümüze gelmeyi ve yașamayı bașaran güçlü yapısıyla, sahip çıkılarak gelecek nesillere sağlıklı șekilde aktarılmayı hak eden çok değerli bir kültürel mirastır.

\section{Kaynakça}

Akkaş, Salih. (1997). "Cumhuriyet Dönemi'nde Türk Müziğinin Türk Müzik 

üzerindeki etkileri üzerine bir araștırma

Eğitimindeki Yeri“ 4. İstanbul Türk Müziği Günleri Türk Müziğinde Eğitim Sempozyumu, İstanbul.

Aksu, Cahit. (2015). “Türkiye'nin Geliștirilecek Ortaokul Müzik Öğretim Programında Bulunması Gereken Bazı Genel Amaçlar",Milli Eğitim Eğitim Ve Sosyal Bilimler Dergisi, 207(4), 56-57.62

Akyüz, Y. (1994). Türk Eğitim Tarihi. İstanbul: Pegem Akademik Yayıncılık.

Ayas, O. Güneș (2014). Müzik İnkılabının Sosyolojisi, İstanbul: Doğu Kitabevi

Coa, Mf. Hus, 16/57

Demircioğlu, Nail (2019). 1923'den Günümüze Ilkokul Ve Ortaokul Müzik Dersi Öğretim Programlarında Geleneksel Türk Müziği Unsurlarının İncelenmesi Ve Değerlendirilmesi, Gazi Üniversitesi Eğitim Bilimleri Enstitüsü Basılmamıș Doktora Tezi, Ankara.

Deniz, Ünsal (2017)."Türk Musikisi İnkılâbı Bağlamında Klasik Türk Musikisi Çalgıları", İnönü Üniversitesi Kültür Sanat Dergisi, Cilt/Vol. 3, Sayı/No 1, S. 28-47.

Ergin, Osman (1977). Maârif Tarihi, İstanbul: Eser Matbaası.

Ertürk, S. (1997). Eğitimde Program Geliștirme. Ankara: Meteksan Matbaacılık Ve Teknik Sanayi A.Ș.

İslamoğlu, Ahmet Hamdi ve Alnıaçık, Ümit (2014). Sosyal Bilimlerde Araștırma Yöntemleri, İstanbul: Beta Basım Yayın Dağıtım A.Ș.
Karasar, Niyazi (2005). Bilimsel Araștırma Yöntemi, Nobel Yayın Dağıtım, Ankara.

Kendüzler, Mustafa (2019). 1995 Yılından İtibaren Ortaokul Müzik Ders Kitaplarında Geleneksel Türk Müzik Türlerinin Yer Alma Durumunun Araștırılması, Gazi Üniversitesi Eğitim Bilimleri Enstitüsü Basılmamış Yükssek Lisans Tezi.

Maârif Vekâleti Talim Ve Terbiye Dairesi (1926), Illk Mektep Kitapları Tedkîk Komisyonunun Mûsikî Kitapları Hakkındaki Raporu, Milli Matbaa, İstanbul.

Millî Eğitim Bakanlığı Talim Ve Terbiye Kurulu Bașkanlığı, Güzel Sanatlar Liseleri Müzik Öğretim Programı 2018, S. 60

Resmî Gazete, (2009) Millî Eğitim Bakanlığı Yönetmeliğinde Türk Millî Eğitiminin Genel Ve Özel Amaçları. Sayı: 27138

Özden, E. (2019). Osmanlı Devleti'nin Konservatuvarı Darülelhan, Ankara: AKM Yayınları.

Özden, E. (2020). Osmanlı Maârifi'nde Mûsikî, Türk Tarih Kurumu Yayınları, Ankara.

Sun, M. (1969). Türkiye'nin Kültür-MüzikTiyatro Sorunları. Ankara: Ajans-Türk.

Tanrıverdi, A. (1997) “Güzel Sanatlar Liselerinin Müzik Bölümlerinde Uygulanan Çalgı Eğitimi Ve Viyolanın Çalgı Eğitimi İçerisindeki Yeri”, Mavi Nota Müzik Ve Sanat Dergisi, Sayı:16.

Uzunçarșılı, İ. Hakkı (1977). "Osmanlılar Zamanında Saraylarda Mûsikî”, Belleten, Ankara, S. 161. 
Varış, Fatma (1996). Eğitimde Program Geliștirme. Ankara: Alkım.

Varol, Necdet (1988). “Müzik-Toplum Etkileșimi”, Birinci Müzik Kongresi Bildirileri 1, 28-33.

İnternet Kaynakları

http: / / www.kultur.gov.tr/TR-96530/ turk-musikisinin yasaklanmasi.html

https://slideplayer.biz.tr/ slide/12564235/

https: / / meslegimhayatim.meb.gov.tr/ photos/2020/06/04/yetenek-sinavi-ekilavuzu-2_5ed8c92575a6c.pdf

https://www.yok.gov.tr/Documents/ Kurumsal/egitim_ogretim_dairesi/ Yeni-Ogretmen-Yetistirme-LisansProgramlari/Muzik_Ogretmenligi_ Lisans_Programi.pdf

https: / / www.nasilolunur.net/muzikogretmeni-nasil-olunur.html?cnreloaded $=1$ 
Türkiye'deki güzel sanatlar liselerinin müzik dersi öğretim programlarının öğrenci alan seçimi üzerindeki etkileri üzerine bir araștırma

Ek- 1: Talim ve Terbiye Kurulu Bașkanlığı'nın Güzel Sanatlar Lisesi Haftalık Ders Çizelgesi Hakkındaki Raporu

T.C.

MílLÎ EĞtirì BAKANIIĞI

Talim ve Terbiye Kurulu Bașkanhğ

\begin{tabular}{|c|c|c|}
\hline Say & 60 & \multirow{4}{*}{$\begin{array}{l}\text { Konu: Ortaōğretim Güzel Sanatlar Lisesi Haftahk Ders } \\
\text { Çizelgesi (Müzile, Türk Halk Müziği, Türk } \\
\text { Sanat Müziög, Görsel Sanatlar) }\end{array}$} \\
\hline Tarih & $19 / 02 / 2018$ & \\
\hline Kurulda Gör. Tarihi & $13 / 02 / 2018$ & \\
\hline $\begin{array}{l}\text { Önceldi Karann } \\
\text { Tarih ve Sayısı }\end{array}$ & $\begin{array}{l}30 / 05 / 2017-53 \\
29 / 06 / 2016-47 \\
29 / 06 / 2016-45 \\
29 / 06 / 2016-43 \\
29 / 06 / 2016-41 \\
27 / 01 / 2014-6\end{array}$ & \\
\hline
\end{tabular}

Ortaōğretim Geael Mũdürlüğinün 22/01/2018-21658195-121.01-E.1605747 ve 05/02/201821658195-121.01-E.2330561 tarhli ve saylı yazlan ủzerine Kurulumuzda görüşülen Güzel Sanatlar Lisesi Haftallk Ders Çizelgesinin (Müzil, Türk Hallk Müziği, Türk Sanat Müziği, Görsel Sanatlar);

1. Ortak ve seçmeli dersler bölümünün 2018-2019 eğitim-ögretim ylından itibaren tüm sunf dỉzeylerinde ekli ômeğine göre uygulanması,

2. Alan derslerinde ise kademeli geçis sürecinin devam etmesi,

Kurulumuzon 30/05/2017 tanhli ve 53 sayll karan ekinde yer alan Gizel Sanatlar Lisesi Haftalik Ders Çizelgesi ile 27/01/2014 tarhli ve 6 saylı karan ekinde yer alan Gïzel Sanatlar Lisesi Haftaluk Ders Çizelgesinin ortak ve seçmeli dersler bötümümün uygulamadan kaldınlması

bususunu uygum gōrüşle arz ederiz.

\section{Dr. Mustafa OTRAR Üye}

Dr. Hasan KAVGACI Üye

Dr. Hüseyin ȘiRín
Uye
Dr. Hüseyin KORKUT

Üye

$\underset{\text { Uâmil YEșiL }}{\text { ÛiL }}$
Doç. Dr. Erkan Dîç
Ûye

Dr. Mehmet SŪRMIELI

Ùye
Alpaslan DURMUS

Kurul Başkanu

UYGUNDUR

.../.../2018

İsmet YIL.MAAZ

Malli Eğitim Bakan 
Ek-2:Osmanlı-Fransız Sanayi Mektebi Ders Programı (Dersler: Mûsikî, Piyano, Keman, Teganni Usûlü)

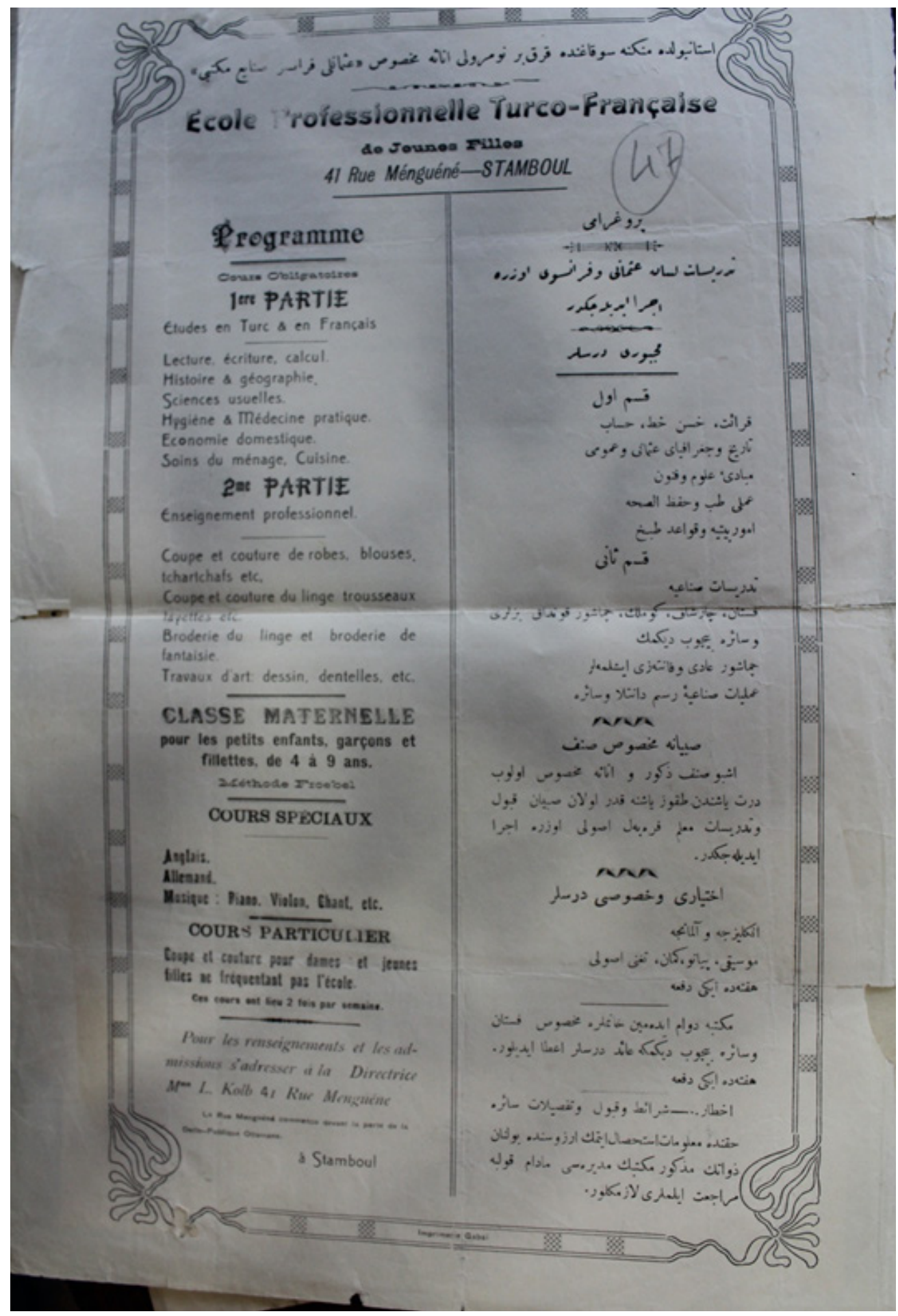


Türkiye'deki güzel sanatlar liselerinin müzik dersi öğretim programlarının öğrenci alan seçimi üzerindeki etkileri üzerine bir araștırma

Ek 3:Maârif Vekâleti Talim ve Terbiye Kurulu’nun 1926 Yılında Yayınlanan Ilkokul Müzik Kitapları Hakkındaki Raporu
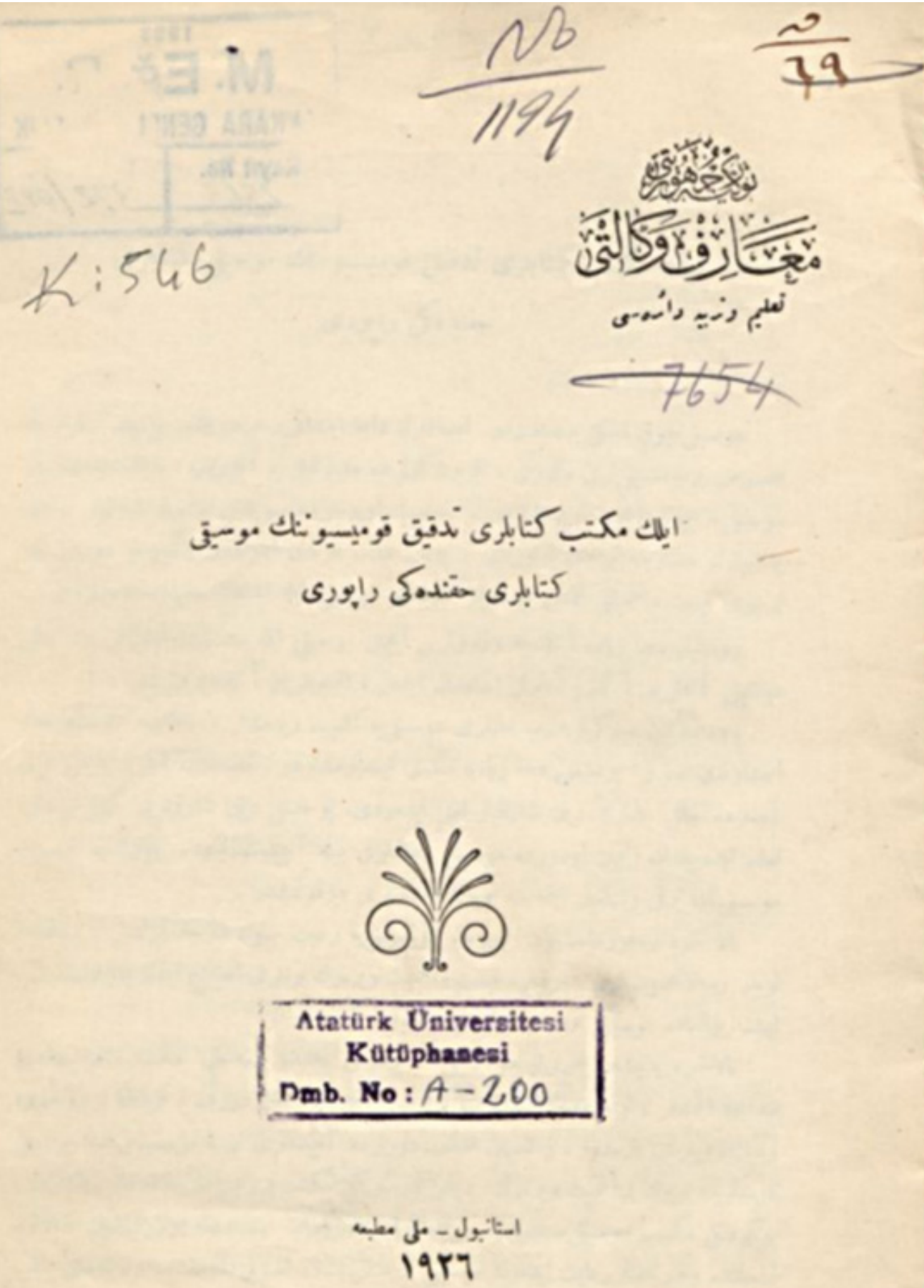


\section{A research on the effects of music course teaching programs of Fine Art Schools in Turkey on Students' field selection}

\section{Extended Abstract}

One of the most striking innovations in Ottoman westernization after the Tanzimat was made in the field of education. The opening of modern schools for the implementation of the education models required by the age, gained momentum towards the end of the nineteenth century. Among these many music schools equivalent to universities and high schools took place. Education programs in the axis of western music have reached today within a similar program and curriculum. Particularly, the contents of the courses determined by music schools based in Istanbul and Ankara played an active role in music education. This situation is similar to the fine arts high schools in our country. The first school of fine arts in Turkey was founded by Avni Akyol, the Minister of Education of the period in 1989 in Istanbul Fine Arts High School are leading institutions of music education at secondary level today. Western-oriented music education models, which have been applied in the conservatory and fine arts faculties from are also applied in these high schools. In this study, it is aimed to examine the effect of the number of courses in the genres Western Music, Turkish Music and Folk Music on the number of students in the music teaching program of the Fine Arts High Schools in our country. For this purpose, the student data of Fine Arts High Schools obtained from the Department of Student Affairs of the Ministry of National Education and the data published by the Board of Education on 19.02.2018 regarding course distributions in the weekly course schedules of the Fine Arts High Schools music teaching program were examined.

\section{Keywords}

fine arts high school, music, turkish music, western music, student 